\title{
POTENTIAL ANTIOXIDATIVE ACTIVITY OF RICE MILLING BY-PRODUCTS
}

\author{
M. A. Salem ${ }^{(1)}$, A. M. Sorour(2) and M.A. El-Bana ${ }^{(2)}$ \\ (1) Food Sci. and Tech. Dept., Fac. of Agric. Tanta Univ., Egypt. \\ (2) Food Tech. Res. Inst., Agric. Res. Center, Giza, Egypt
}

Received: Oct. 18, 2017

Accepted: Nov. 21,2017

\begin{abstract}
This investigation was carried out to study the possibility of extraction of some natural antioxidative phenolic compounds from rice milling by-products (defatted black rice bran, defatted white rice bran, black rice hull and white rice hull). The extracted phenolic compounds were tested as natural antioxidants using cotton seed oil after deep frying $(170-180)^{\circ} \mathrm{C}$ of potato for 25 hours.

The results indicated that Ethanol gave the highest extract yield of all extracts. Ethanol exhibited the highest extraction ability for phenolic compound (5.31, 4.80, 2.90 and $2.10 \mathrm{mg} / \mathrm{g}$ ), for Defatted black rice bran, Defatted white rice bran, white rice hull, and black rice hull extracts, respectively and also showed the strongest antioxidant activity of Defatted black rice bran extract activity owing to its high content of phenolic and flavonoids compounds.

Ferulic acid was the major phenolic compounds presented and identified in defatted black rice bran; defatted white rice bran and black rice hull while, Caffeic acid was the major phenolic compounds presented and identified in White rice hull. The highest inhibition ratio IC50 was (0.097) found in TBHQ extract following by Defatted black rice bran, Defatted white rice bran, Black rice hull and White rice hull.

Peroxide value, Thiobarbituric acid (TBA) value and polymer content of cotton seed oil increased by increase of frying time, furthermore, defatted black rice bran ethanolic extract (400 ppm) was more effective as antioxidant than those of the other studied by-products of the rice milling .
\end{abstract}

Key word: Rice milling-phenolic-deep frying - Peroxide value

\section{INTRODUCTION}

Lipid oxidation has been identified as the major deterioration process of vegetable oils affecting both the sensory and the nutritional quality of foods. Frying is one of the most common cooking techniques used in domestic and industrial food preparation. Flavour, shelf-life and nutrient composition of fried food and vegetable oils are altered by this process, and also some of the compounds formed may have undesirable consequences on consumers' health (Hosseini et al., 2016).

Antioxidant compounds are gaining importance due to their dual role in the food industry as lipid stabilizers and in preventive medicine as suppressors of excessive oxidation that causes cancer and ageing Devi et al. (2007)

Synthetic antioxidants such as butylated hydroxy toluene (BHT), butylated hydroxyl anisole (BHA) or tertabutyl hydroquinone (TBHQ) are often used to retard lipid oxidation in food systems. Due to their low thermal stability, the concern about their long term effects on human health and the increasing demand by consumers for natural products, plant extracts emerged as good alternatives to synthetic antioxidants (Sahin et al., 2017).

Studies have shown that cereal grains, especially rice, contain special phenolic acids (such as ferulic acid, p-coumaric and diferulate) that are not present in significant 
quantities in fruit and vegetables (Adom and Liu, 2002).

Rice, being one of the most produced and consumed cereals in the world, has an important role in the relation between the diet and health. Several compounds with antioxidant activity have been identified in rice, including phenolic compounds, tocopherols, tocotrienols and $\boldsymbol{\gamma}$-oryzanol (Iqbal et al., 2005). The phenolic compounds are mainly associated with the pericarp in rice, hence, the milling process reduces the concentration of these compounds in the grain. Besides, grains with darker pericarp colour, such as red and black rice, contain higher amounts of polyphenols (Walter and Marchesan,2011). In addition, the concentration of total phenolics in the grain has been positively associated with the antioxidant activity, with potential beneficial effects on health, such as reduction of oxidative stress, aid in the prevention of cancer, in the control of blood lipids and related diseases, which may help in the prevention of cardiovascular problems, and in the prevention of the complications of diabetes (Zhang et al., 2006 and Yawadio et al., 2007).

Jeon et al. (2006) reported that phenolic compounds, from methanolic extracts of rice hull, exhibit high antioxidant activity against scavengers of singlet oxygen and inhibit high hydrogen peroxide -induced damage to cellular deoxy nucleic acid (DNA) in human lynphocytes. Furthermore, in black rice hull , cyaniding glucoside has been reported to be one of the major antioxidant compounds (Osawa, 1999 ).

Colored rice are reported as potent sources of antioxidants and encourage ments as viable sources of antioxidants for functional foods (Yawadio, et al., 2007).

The present study was under taken to evaluate the efficiency of the polyphenolic extracts from different rice milling byproducts (defatted black and white rice brans, black rice hull and white rice hull) as a new sources of natural antioxidants for inhibiting the rancidity of fried cotton seed oil.

\section{MATERIALS AND METHODS \\ 1.Materials:}

White rice hull and bran of Sakha 101 as well, black hull and bran were obtained from the Rice Research and Training Center (RRTC), Sakha, Kafer El-Sheikh, Egypt, Season 2016 and stored at $-20^{\circ} \mathrm{C}$ until further use. Commercial antioxidant; Tetra butyled hydroxyl quinone (TBHQ), 1,1diphenyl -2 -picrylhydrazyl (DPPH) , Folinciocalteau reagents, Thiobarbituric acid (TBA 98\%) were purchased from SigmaAldrich Co. (St. Louis, Mo., U.S.A.) and cotton seed oil (antioxidant free)were: obtained from Tanta Company for Oils and Soap, Tanta, Egypt, (2016)

\section{Methods:}

\subsection{Samples preparation:}

The black rice bran and white rice bran $(20 \mathrm{~g})$ were soaked in $100 \mathrm{ml} \mathrm{n}$-hexane at room temperature $(25 \pm 2){ }^{\circ} \mathrm{C}$ for $48 \mathrm{hr}$, then filtrated through Whatman No.1 filter paper. The residues were re-extracted three times using fresh solvent each time to extract most of the oils from the samples.

\subsection{Extraction of natural antioxidants from rice by- product:}

The prepared ground materials $(10 \mathrm{~g})$ of each sample were soaked in $100 \mathrm{ml}$ of each solvent (Ethanol, Ethyl acetate, Acetone and Diethyl ether) overnight in a shaker at room temperature according to Mohdaly et al (2010). The extracts were filtrated through Whatman No.1 filter paper. The residues were re-extracted three time under the same conditions. The combined filtrates were evaporated under vacuum in a rotary evaporator below $40^{\circ} \mathrm{C}$. The extracts obtained after evaporation of organic solvents were weighted to determine the extract yield and stored at $-20^{\circ} \mathrm{C}$ until further analysis. 


\subsection{Determination of total phenolic compounds:-}

Total phenolic compounds of the extracts were determined spectrophoto metrically using Folin-ciocalteau reagent according to the method described by Bonoli et al. (2004) and used to estimate the phenolics-acid content using a standard curve prepared using tannic acid.

\subsection{Determination of total flavonoids:}

Total flavonoid was determined by the method of Ordonez et al. (2006). and used to estimate the flavonoids content using a standard curve prepared using catechol acid.

\subsection{Identification of phenolic compounds by HPLC:}

Phenolic compounds of rice by-products samples were extracted according to the method outlined by Evangelisti et al., 1997.

\subsection{Evaluation of Antioxidant activity of extracts(AA): Determination of DPPH - radical scavenging capacity: \\ The1,1-diphenyl-2-picrylhydrazyl (DPPH) assay (Lee et al., 2003) . \\ $I_{50}$ values, which correspond to the concentration of rice by-products extracts that caused a $50 \%$ neutralization of DPPH•, were calculated from the plot of percent $\mathrm{DPPH} \bullet$ scavenging versus concentration.}

\subsection{Measurement of stability:}

The oxidative stability of oils were estimated according to the method described by the Tsaknis et al. (1999) by rancimate method using 679 Rancimate (Metrohm, Herisav, Switzerland) at $100^{\circ} \mathrm{C}$ with air flow rate at $20 \mathrm{~L} / \mathrm{hr}$.

\subsection{Antioxidative assay of phenolic extracts:}

The antioxidative activities of poly phenolic extracts were assayed by addition of each extract at $400 \mathrm{ppm}$ level of its polyphenols content and TBHQ 200 ppm to cotton seeds oil free of antioxidants.

\subsection{Frying performance:}

Cottonseed oil $(3 \mathrm{~kg})$ were heated in a domestic fryer (Model $7122 \mathrm{~A}$, Tefal Super 500 deluxe, France) to $185 \pm 5^{\circ} \mathrm{C}$. Potato tubers were first washed with tap water then manually peeled, cut into $5.0 \times 0.7 \times 0.7 \mathrm{~cm}$ pieces using mechanical cutter (type chef, La Minerva, Italy) and submerged in tap water until frying. After draining off excess water, $200 \mathrm{~g}$ of them were placed in a wire basket and deep fried in the tested cotton seed oils as follows:

1. Free from antioxidants, heated control.

2. Containing (200 ppm) Tetra butyled hydroxyl quinone (TBHQ).

3. Containing $(400 \mathrm{ppm})$ from ethanolic extracted rice milling by-products .

The frying process was daily repeated for five hours. The heating frying cycle was continued for five days. At the end of each frying period, the oil was filtered through muslin to remove the remaining fried particles, allowed to cool overnight at room temperature. Two hundred $\mathrm{ml}$ of the filtered oils were taken and preserved in dark glass bottles with stoppers in a refrigerator until analyzed.

2.8.1.Peroxide value (PV): was determined by potassium iodide method according to Leonard et al. (1987).

2.8.2. Thiobarbituric acid (TBA): values were determined according to Sidwell et al. (1990). The concentration of malonaldehyde in oil samples were calculated from standard curve. Absorbance was read at $532 \mathrm{~nm}$ against distilled water.

2.8.3. Polymer content: were determined according to the method outlined by $\mathrm{Wu}$ and Nawer (1986)

\subsection{Statistical analysis:}

Most of the received data were analyzed statistically using the analysis of variance 
and the means were further tested using the least significant difference test (LSD) as outlined by Steell and Torrie (1980).

\section{RESULTS AND DISCUSSION}

\section{Effect of using different solvents on Total polyphenols content of extracted from rice milling by- products:}

Phenolics are antioxidants, and there is a general belief that the phenolics present in plant food contribute to prevent the oxidative damage that is implicated in a range of diseases, including cancer, cardiovascular diseases and aging (Scalbert et al., 2005).

The data in Table (1) concluded that ethanol was the best solvent for extracting polyphenols from rice milling by-products. The amounts of ethanolic could be arranged in the following decreasing order extracted polyphenolic compounds by ethanol from defatted black rice bran $(5.31 \mathrm{mg} / 100 \mathrm{~g})$, defatted white rice bran $(4.80 \mathrm{mg} / 100 \mathrm{~g}$, black rice hull $(2.90 \mathrm{mg} / 100 \mathrm{~g})$ and finally white rice hull $(2.10 \mathrm{mg} / 100 \mathrm{~g})$. These results are agreement with the results obtained by Butsat and Siriamornpun (2010).; Araba et al. (2011) and Pitchaporn, and Sirithon (2016). On the other hand, the data in the same Table showed that, defatted black rice bran contained highest amounts of polyphenolic compounds with all using solvents comparing with other different byproducts in the rice milling. These result agreement with Zhang et al. (2006) whom reported that black rice contains rich of polyphenolic compound much more white rice.

\section{Effect of solvent on extracted total flavonoids from rice milling by-products:}

Data in Table (2) showed that, defatted black rice bran extracts had the highest total flavonoids contents, with values ranging from 0.21 to $0.53 \mathrm{mg}$ Catechol equivalent $/ \mathrm{g}$ followed by defatted white rice bran extracts with values ranging from 0.19 to $0.36 \mathrm{mg}$ Catechol equivalent $/ \mathrm{g}$ then Black rice hull extracts with values ranging from 0.10 to $0.27 \mathrm{mg}$ Catechol equivalent $/ \mathrm{g}$ and finally White rice hull extracts with values ranging from 0.08 to $0.19 \mathrm{mg}$ Catechol equivalent/ $g$, depending on the solvent used for extraction. The highest flavonoids contents were observed in ethanolic extracts. These results are in agreement with Goufo et al. (2014).

Table (1): Effect of using different solvents on extracted Total polyphenols content from rice milling by-products. (mg Tannic acid/100g of Dry Weigh)

\begin{tabular}{|l|c|c|c|c|}
\hline \multirow{2}{*}{$\begin{array}{l}\text { Extraction } \\
\text { solvent }\end{array}$} & \multicolumn{4}{|c|}{ Tot Total polyphenols (mg Tannic acid/100g of Dry Weigh) } \\
\cline { 2 - 5 } & $\begin{array}{c}\text { defatted Black } \\
\text { rice bran }\end{array}$ & $\begin{array}{c}\text { defatted white } \\
\text { Rice bran }\end{array}$ & Black Rice hull & white rice hull \\
\hline Ethanol & $5.31^{\mathrm{a}}$ & $4.8^{\mathrm{a}}$ & $2.9^{\mathrm{a}}$ & $2.1^{\mathrm{a}}$ \\
\hline Acetone & $4.1^{\mathrm{b}}$ & $2.4^{\mathrm{b}}$ & $2.3^{\mathrm{b}}$ & $1.7^{\mathrm{b}}$ \\
\hline Ethyl acetate & $2.7^{\mathrm{c}}$ & $2.3^{\mathrm{c}}$ & $1.3^{\mathrm{c}}$ & $1.0^{\mathrm{c}}$ \\
\hline Diethyl ether & $2.4^{\mathrm{d}}$ & $1.9^{\mathrm{d}}$ & $1.0^{\mathrm{d}}$ & $0.8^{\mathrm{d}}$ \\
\hline
\end{tabular}

Each value is an average of three determinations

Values followed by the same letter in columns are not significantly different at $\mathrm{P}<0.05$ 
Potential antioxidative activity of rice milling by-products

Table (2): Effect of solvent on extracted total flavonoids from rice milling by-products.

\begin{tabular}{|l|c|c|c|c|}
\hline \multirow{2}{*}{$\begin{array}{l}\text { Extraction } \\
\text { solvent }\end{array}$} & \multicolumn{3}{|c|}{ Total flavonoid content(mg Catechol equivalent/g) } \\
\cline { 2 - 5 } & $\begin{array}{c}\text { Defatted black } \\
\text { rice bran }\end{array}$ & $\begin{array}{c}\text { Defatted white rice } \\
\text { bran }\end{array}$ & Black rice hull & White rice hull \\
\hline Ethanol & $0.53^{\mathrm{a}}$ & $0.36^{\mathrm{a}}$ & $0.27^{\mathrm{a}}$ & $0.19^{\mathrm{a}}$ \\
\hline Ethyl acetate & $0.39^{\mathrm{b}}$ & $0.26^{\mathrm{b}}$ & $0.21^{\mathrm{b}}$ & $0.16^{\mathrm{b}}$ \\
\hline Acetone & $0.25^{\mathrm{c}}$ & $0.20^{\mathrm{c}}$ & $0.13^{\mathrm{c}}$ & $0.11^{\mathrm{c}}$ \\
\hline Diethyl ether & $0.21^{\mathrm{c}}$ & $0.19^{\mathrm{c}}$ & $0.10 \mathrm{c}$ & $0.08^{\mathrm{c}}$ \\
\hline
\end{tabular}

Each value is an average of three determinations

Values followed by the same letter in column are not significantly different at $P<0.05$.

\section{Identification of polyphenols compound of rice milling ethanolic extracts.}

The aforementioned set of experiments relevant to the antioxidant efficiency of the total polyphenols extracts (defatted black rice bran, defatted white rice bran, black rice hull and white rice hull) and demonstrated that the total polyphenols compounds possessed remarkable antioxidant activity. Therefore, it is quite necessary to characterize the phenolic compounds of total polyphenols extracts. High performance liquid chromatography (HPLC) was used for the qualitative and quantitative determination of total polyphenols. Table (3) indicated that, the most abundant phenolic acids in by- products of the rice milling were Ferulic, p-coumaric, vanillic and Caffeic acids furthermore Ferulic acid was the major phenolic compounds presented and identified in defatted black rice bran; defatted white rice bran and black rice hull while, Caffeic acid was the major phenolic compounds presented and identified in White rice hull .These result agree with Zaupa et al. (2015)

On the other hand, our finding that ferulic acid is the major component found in bran rice makes sense if it is linked to arabinoxylan in cell walls of the aleurone layers (McKeehen, et al., 1999) .

\section{Antioxidant activity (DPPH) of crude rice milling by-product ethanolic extracts. \\ The free redical scavenging of the} ethanolic extracts of crude rice milling byproduct were evaluated using the DPPH method and the results showed that antioxidant activity of by-products of the rice milling ethanolic extract in ranged from 100 $\mathrm{ppm}$ to $400 \mathrm{ppm}$ (compared with synthetic antioxidant TBHQ). The results cleared that antioxidant activity of TBHQ was higher than all extracts at different level (table4). These findings are in close agreement with previous findings of (Butsat and Siriamornpun ,2010.; Yao et al., 2010.and Pitchaporn, and Sirithon (2016). In addition, The DPPH radical scavenging of defatted black rice bran, defatted White rice bran, black rice hull, white rice hull and TBHQ in concentration of $400 \mathrm{ppm}$ were $82.75,80.3$ ,74.4, 72.9 and $95.2 \%$. The varied radical scavenging activity of the extracts depended on the amount of total phenolic. Also, the highest inhibition ratio $\mathrm{IC}_{50}(0.097)$ was found in TBHQ extract following by defatted black rice bran (0.182), defatted White rice bran (0.195), black rice hull (0.215) and white rice hull (0.223). This finding supports the data previously reported in a study where the antioxidant activity was dependent on the actual composition of milling fraction (Liyana-Pathirana and Shahidi 2007). 
M. A. Salem, et al.,

Table (3): Identification of polyphenolic compounds $(\mathrm{mg} / 100 \mathrm{~g})$ of defatted black rice bran, defatted white rice bran, black rice hull and white rice hull:

\begin{tabular}{|c|c|c|c|c|}
\hline \multirow{2}{*}{$\begin{array}{l}\text { Phenolic compounds } \\
\text { contents }\end{array}$} & \multicolumn{4}{|c|}{ by- products of the rice milling } \\
\hline & $\begin{array}{l}\text { defatted black } \\
\text { rice bran }\end{array}$ & $\begin{array}{l}\text { defatted white } \\
\text { rice bran }\end{array}$ & $\begin{array}{c}\text { black rice } \\
\text { hull }\end{array}$ & $\begin{array}{c}\text { white rice } \\
\text { hull }\end{array}$ \\
\hline Benzoic acid & ND & ND & 1.02 & 22.3 \\
\hline Catechol acid & 0 & 1.38 & ND & ND \\
\hline Chtechin acid & 4.01 & 4.06 & ND & 1.78 \\
\hline Protocatechuic acid & 2.6 & ND & ND & ND \\
\hline Caffien acid & 25.5 & ND & 1.98 & 44.8 \\
\hline EL lagalic acid & ND & ND & ND & 21.3 \\
\hline p-coumaric Acid & 37.7 & 29.5 & 22.3 & 4.53 \\
\hline Vanilic acid & 11.84 & 85.5 & 8.16 & 13.2 \\
\hline Gallic acid & 0 & 0.43 & 1.26 & 1.08 \\
\hline Ferulic acid & 121.9 & 87.4 & 40.01 & 29.93 \\
\hline Pyrogallol acid & ND & 8.83 & ND & 8.54 \\
\hline Syringic acid & 0.71 & ND & ND & ND \\
\hline Caffeic acid & 27.55 & 16.09 & 36.5 & 84.1 \\
\hline Chlorogenic acid & 1.54 & 0.97 & 4.79 & 2.27 \\
\hline Salicylic acid & ND & ND & 10.3 & ND \\
\hline Chrysin & 0.77 & ND & ND & ND \\
\hline
\end{tabular}

ND : not detected

Table (4): Antioxidant activity by (DPPH) assays of crude rice milling by-product ethanolic extracts.

\begin{tabular}{|l|c|c|c|c|c|}
\hline \multirow{2}{*}{ Samples } & \multicolumn{3}{|c|}{ DPPH Scavenging(\%) } & \multirow{2}{*}{$\begin{array}{c}\text { IC } 50 \% \\
\mathrm{ng} / \mathrm{ml}\end{array}$} \\
\cline { 2 - 5 } & $100(\mathrm{ppm})$ & $200(\mathrm{ppm})$ & $300(\mathrm{ppm})$ & $400(\mathrm{ppm})$ & \\
\hline TBHQ & $80.2^{\mathrm{a}}$ & $86.31^{\mathrm{a}}$ & $92.8^{\mathrm{a}}$ & $95.2^{\mathrm{a}}$ & 0.097 \\
\hline Defatted black rice bran & $46.6^{\mathrm{b}}$ & $63.2^{\mathrm{b}}$ & $74.4^{\mathrm{b}}$ & $82.75^{\mathrm{b}}$ & 0.182 \\
\hline Defatted white rice bran & $42.2^{\mathrm{c}}$ & $60.01^{\mathrm{c}}$ & $71.3^{\mathrm{c}}$ & $80.3^{\mathrm{c}}$ & 0.195 \\
\hline Black rice hull & $37.4^{\mathrm{d}}$ & $56.1^{\mathrm{d}}$ & $68.8^{\mathrm{d}}$ & $74.4^{\mathrm{d}}$ & 0.215 \\
\hline White rice hull & $35.9^{\mathrm{e}}$ & $54.5^{\mathrm{e}}$ & $66.75^{\mathrm{e}}$ & $72.9^{\mathrm{e}}$ & 0.223 \\
\hline
\end{tabular}

Each value is an average of three determinations

Values followed by the same letter in columns are not significantly different at $\mathrm{P}<0.05$ 


\section{Effect of polyphenolic extracts on the oxidative stability of cotton seed oil:}

The polyphenolic compounds extracted from rice milling by-products were added to cotton seed oil with the concentration of 100 , 200 and 400 ppm and 200 ppm of TBHQ. The stability of cotton seed oil was measured at $100 \mathrm{C}^{\circ}$ by rancimat method. It is clear that the addition of ethanolic extracted from rice milling by-products increase the stability of cotton seed oil at all levels. Induction period of cotton seed oil increased to $10.60,9.40,8.90$, and 8.80 hrs. With 400 ppm of ethanol extracts of defatted black rice bran, defatted white rice bran, black rice hull and white rice hull respectively. While, it was increased to $8.3 \mathrm{hr}$. by addition of TBHQ at 200 ppm concentration. These compounds are considered to be beneficial to health since, they act as antioxidants in the body by inhibiting lipid peroxidation scavenging, free radical and displaying antimutagenic properties. Similar results were obtained by Delfanian, et al. (2016), who discovered that a high polyphenol content was associated with high resistance of oxidation.

The percentage of antioxidant activity (A.A.) was calculated and also presented in Table (5). Hence, it could be noticed that defatted black rice bran extract had the highest antioxidant activity among the investigated extracts followed by defatted white rice bran, black rice hull then white rice hull extract which had the lowest antioxidant activity. The antioxidant activity of the phenolic compounds had been also investigated by Nam et al. (2006), who reported that pigmented of rice extracts scavenged superoxide anions more effectively than hydroxyl radical. Furthermore, Pyo et al. (2004) found that a positive linear correlation $(R=0.943)$ was demonstrated between radical scavenging activity and total phenolic content of each extract.

In addition, all rice fractions (except for milled rice) showed the ability to scavenge the $\mathrm{DPPH}_{-}$radical at a rate higher than TBHQ (0.2 $\mathrm{mg} / \mathrm{ml})$ (Liyana-Pathiranaand Shahidi, 2007).

Table (5): Effect of ethanolic extracts on the oxidative stability of cotton seed oil.

\begin{tabular}{|c|c|c|c|c|c|c|}
\hline \multirow[t]{3}{*}{ Polyphenolic sources } & \multicolumn{6}{|c|}{ ethanolic concentration } \\
\hline & 100ppm & 200 pm & 400ppm & 100ppm & 200ppm & $400 \mathrm{pm}$ \\
\hline & \multicolumn{3}{|c|}{ Induction period (hr) } & \multicolumn{3}{|c|}{ Antioxidant activity(A.A\%)* } \\
\hline Cotton seed oil (control) & \multicolumn{3}{|c|}{4.2} & \multicolumn{3}{|c|}{0} \\
\hline TBHQ & & 8.3 & - & - & 98 & - \\
\hline defatted black rice bran & 8.1. & 9.40 & 10.60 & 93 & 124 & 152 \\
\hline defatted white rice bran & 7.80 & 8.90 & 9.40 & 86 & 112 & 124 \\
\hline Black rice hull & 7.20 & 8.40 & 8.90 & 71 & 100 & 112 \\
\hline black rice hull & 7.0 & 8.20 & 8.80 & 67 & 95 & 110 \\
\hline
\end{tabular}

A.A. $\%=\underline{\text { Induction period of sample-induction period of control }} \times 100$ Induction period of control 


\section{Effect of using ethanolic extracts from rice milling by- product on chemical properties of cotton seed oil:}

\section{1.peroxide value (PV):}

The data presented in Table (6) illustrate that, PV of cotton seed oil was increased by increasing the frying hours. On the other hand, PV for oils treated by defatted black rice bran, defatted white rice bran, black rice hull, white rice hull phenolic extracts at 400 ppm concentration, TBHQ at $200 \mathrm{ppm}$ concentration and control were increased to $19.40,19.60,19.80,19.90,19.80$ and 26.30 $\mathrm{meq} / \mathrm{kg}$ oil for 25 hours, respectively. Defatted black rice bran phenolic extract had the highest activity in increasing the thermal oxidation. These results are consistent with findings of Upadhyay et al. (2017) Who reported that lipid peroxides were significantly reduced by the addition of antioxidants in Thermal processed oil.

\subsection{Thiobarbituric acid (TBA)}

There are two stages of oil oxidation, i.e., the first stage is the formation of hydro peroxides and the second one is the decomposition of hydroperoxides to produce secondary oxidation products which could be react with TBA reagent to produce coloured compounds which absorb usually at $530 \mathrm{~nm}$ (Orthoefer, et al., 1996).

Thiobarbituric acid (TBA) of fresh and fried cotton seed oil was determined and the results are presented in Table (7). The rates of TBA values were rapidly increased with increasing the frying period of control. Comparing to heated control $(8.0 \mathrm{mg}$ malonaldhyde/kg oil) for 25 hours frying, all antioxidant extracts and TBHQ decreased the TBA value to $3.1,3.4,3.9,4.2$ and 4.05 $\mathrm{mg}$ malonaldhyde $/ \mathrm{kg}$ oil, when defatted black rice bran, defatted white rice bran, hull black rice, hull white rice at $400 \mathrm{ppm}$ concentration and TBHQ at $200 \mathrm{ppm}$ concentration were used, respectively. Generally, Table (7) also cleared that, defatted black rice bran extract was more effective as antioxidant than those of the other studied by-products and TBHQ. Similar results were obtained by. Devi et al. (2007) showed that the defatted rice bran (DRB) extracts were stable at high temperatures and therefore capable of protecting soybean oil against oxidation even at elevated temperatures.

Table (6): Effect of ethanolic extracts from rice milling by-product on peroxide value (PV) during the deep frying of cotton seed oil.

\begin{tabular}{|c|c|c|c|c|c|c|}
\hline \multirow{3}{*}{ Frying time(h) } & \multirow[b]{2}{*}{ Control* } & \multirow{2}{*}{$\begin{array}{l}\text { TBHQ } \\
200 \\
\mathrm{ppm}\end{array}$} & \multicolumn{4}{|c|}{$\begin{array}{l}\text { ethanolic extracts from rice milling by-product at } 400 \\
\text { ppm conc. }\end{array}$} \\
\hline & & & $\begin{array}{c}\text { Defatted } \\
\text { black rice } \\
\text { bran }\end{array}$ & $\begin{array}{l}\text { Defatted } \\
\text { white rice } \\
\text { bran }\end{array}$ & $\begin{array}{l}\text { black rice } \\
\text { hull }\end{array}$ & $\begin{array}{c}\text { White rice } \\
\text { Hull }\end{array}$ \\
\hline & \multicolumn{6}{|c|}{ Peroxide value (meq/kg oil) } \\
\hline 0 & 7. $0^{\mathrm{Af}}$ & $7.0^{\text {Af }}$ & $7.0^{\mathrm{Ae}}$ & 7.0 Af & 7. $0^{\mathrm{Af}}$ & $7.0^{\mathrm{Af}}$ \\
\hline 5 & $12.5^{\mathrm{Ae}}$ & $10.5^{\mathrm{Be}}$ & $10.3^{\mathrm{Dd}}$ & $10.4^{\mathrm{Ce}}$ & 10.3 De & $10.5^{\mathrm{Be}}$ \\
\hline 10 & $15.6^{\mathrm{Ad}}$ & $11.9^{\mathrm{Cd}}$ & $12.6^{\mathrm{Bc}}$ & $11.9^{\mathrm{Cd}}$ & $12.1^{\mathrm{Bd}}$ & $11.9^{\mathrm{Cd}}$ \\
\hline 15 & $18.4^{\mathrm{Ac}}$ & $14.2^{\mathrm{BC}}$ & $13.8^{\mathrm{Cc}}$ & $14.0^{c c}$ & $14.4^{\mathrm{Bc}}$ & $14.3^{\mathrm{BC}}$ \\
\hline 20 & $19.3^{\mathrm{Ab}}$ & $16.9^{\mathrm{Bb}}$ & $16.9^{\mathrm{Bb}}$ & $16.8^{\mathrm{Cb}}$ & $17.1^{\mathrm{Bb}}$ & $16.9^{\mathrm{Bb}}$ \\
\hline 25 & $26.3^{\mathrm{Aa}}$ & $19.8^{\mathrm{Ba}}$ & $19.4^{\mathrm{Ca}}$ & $19.6^{\mathrm{Ba}}$ & $19.8^{\mathrm{Ba}}$ & $19.9 \mathrm{Ba}$ \\
\hline
\end{tabular}

Each value is an average of three determinations \pm standard devasion

in column; means with the same small supercript letters are not significantly different at $0.05 \%$.

in a raw means with the same capital superscript letters are not significantly different at $0.05 \%$

* Free from antioxidants. 
Table (7): Effect of ethanolic extracts from rice milling by-product on Thiobarbituric acid (T.B.A) during the deep oil.

\begin{tabular}{|c|c|c|c|c|c|c|}
\hline \multirow[b]{3}{*}{ Frying time $(\mathrm{h})$} & \multirow[t]{2}{*}{ Control* } & \multirow{2}{*}{$\begin{array}{c}\text { TBHQ } \\
\text { (200 ppm) }\end{array}$} & \multicolumn{4}{|c|}{$\begin{array}{l}\text { ethanolic extracts from rice milling by-product_at } \\
\qquad 400 \text { ppm conc. }\end{array}$} \\
\hline & & & $\begin{array}{c}\text { Defatted } \\
\text { black rice } \\
\text { bran }\end{array}$ & $\begin{array}{c}\text { Defatted } \\
\text { white rice } \\
\text { bran }\end{array}$ & $\begin{array}{l}\text { black rice } \\
\text { hull }\end{array}$ & $\begin{array}{l}\text { white rice } \\
\text { hull }\end{array}$ \\
\hline & \multicolumn{6}{|c|}{ TBA (mg malonaldhyde/kg oil) } \\
\hline 0 & $0.71^{\mathrm{Ae}}$ & $0.71 \mathrm{~A}^{\mathrm{de}}$ & $0.71^{\mathrm{Ad}}$ & $0.71^{\text {Ad e }}$ & $0.71^{\text {Ade }}$ & $0.71^{\mathrm{Ad}}$ \\
\hline 5 & $1.89^{\mathrm{Ad}}$ & $0.61^{\mathrm{Ce}}$ & $0.66^{\mathrm{Bd}}$ & $0.62^{\mathrm{Ce}}$ & $0.60^{\mathrm{Ce}}$ & $0.61^{\mathrm{Cd}}$ \\
\hline 10 & $2.85^{\mathrm{Ac}}$ & $0.80^{C d}$ & $0.75^{\mathrm{Bd}}$ & $0.80^{c d}$ & $0.83^{\mathrm{Cd}}$ & $0.75^{\mathrm{Bd}}$ \\
\hline 15 & $3.9^{A b}$ & $1.80^{\mathrm{Bc}}$ & $1.60^{\mathrm{Cc}}$ & $1.75^{\mathrm{cc}}$ & $1.85^{\mathrm{Bc}}$ & $1.9^{\mathrm{Bc}}$ \\
\hline 20 & $7.9 \mathrm{Aa}$ & $2.92^{\mathrm{Cb}}$ & $2.01^{\mathrm{Db}}$ & $2.8^{\mathrm{Cb}}$ & $3.10^{\mathrm{Bb}}$ & $3.3^{\mathrm{Bb}}$ \\
\hline 25 & $8.0^{\mathrm{Aa}}$ & $4.05^{\mathrm{B} \mathrm{a}}$ & $3.1^{\mathrm{Ca}}$ & $3.4^{\mathrm{Ca}}$ & $3.9^{\mathrm{Ba}}$ & $4.2^{\mathrm{B} \mathrm{a}}$ \\
\hline
\end{tabular}

Each value is an average of three determinations \pm standard devasion

in column; means with the same small supercript letters are not significantly different at $0.05 \%$.

in a raw means with the same capital superscript letters are not significantly different at $0.05 \%$

TBHQ: tetra butyled hydroxyl quinine

* Free from antioxidants.

\subsection{Effect of ethanolic extracts from rice milling by-product on insoluble polymer (\%) content during the deep frying of oil.}

The result in Table (8) illustrated that, the insoluble polymer content values of oil increased during frying and were strongly correlated with prolonging the frying period. During frying, oils are hydrolysed to form FFA, monoglyceride, diglycerides and these compounds accumulate in the frying oil with repeated use. In addition, oils also oxidized to form hydroperoxide, conjugated dienoic acids, epoxides, hydroxides, aldehydes and ketones. These compounds may undergo fission into smaller fragments or may remain in the triglyceride molecule and cross-link with each other, leading to dimeric and higher polymeric triglycerides (Innawonga et al ., 2004).

On the other hand, insoluble polymer content for oil contained ethanolic extracted from by Defatted black rice bran, Defatted white rice bran, Black rice hull, White rice hull at $400 \mathrm{ppm}$ concentration, TBHQ at 200 ppm concenteration and control were increased to 2.38, 2.42, 2.48, 2.52, 2.4 and $3.2 \%$ oil for 25 hours respectively These result agreement with Ali. (2010) and Basuny et al. (2013) . 
Table (8): Effect of using ethanolic extracts from rice milling by-product on insoluble Polymer content (\%) of oil during the deep frying of oil.

\begin{tabular}{|c|c|c|c|c|c|c|}
\hline \multirow{2}{*}{ Treatment } & \multirow[t]{2}{*}{ Control* } & \multirow[t]{2}{*}{$\begin{array}{c}\text { TBHQ } \\
\text { (200ppm) }\end{array}$} & \multicolumn{4}{|c|}{$\begin{array}{l}\text { ethanolic extracts from rice milling by-product } \\
\qquad(400 \mathrm{ppm})\end{array}$} \\
\hline & & & $\begin{array}{l}\text { Defatted } \\
\text { black } \\
\text { rice bran }\end{array}$ & $\begin{array}{l}\text { Defatted } \\
\text { white } \\
\text { rice bran }\end{array}$ & $\begin{array}{l}\text { Black rice } \\
\text { hull }\end{array}$ & $\begin{array}{l}\text { White } \\
\text { rice hull }\end{array}$ \\
\hline 0 & $0.17^{\text {Af }}$ & $0.17^{\mathrm{Af}}$ & $0.17^{\text {Af }}$ & $0.17^{\text {Af }}$ & $0.17^{\mathrm{Af}}$ & $0.17^{\mathrm{Af}}$ \\
\hline 5 & $0.82^{\mathrm{Ae}}$ & $0.52^{\mathrm{Ce}}$ & $0.50^{\mathrm{Ce}}$ & $0.57^{\mathrm{Be}}$ & $0.59^{\mathrm{Be}}$ & $0.6^{\mathrm{Be}}$ \\
\hline 10 & $1.64^{\mathrm{Ad}}$ & $0.98^{\mathrm{Cd}}$ & $0.98^{\mathrm{Cd}}$ & $1.04^{\mathrm{Bd}}$ & $1.14^{\mathrm{Bd}}$ & $1.2^{\mathrm{Bd}}$ \\
\hline 15 & $2.4^{\mathrm{AC}}$ & $1.48^{\mathrm{Dc}}$ & $1.45^{\mathrm{Dc}}$ & $1.58^{\mathrm{Cc}}$ & $1.59^{\mathrm{Cc}}$ & $1.68^{\mathrm{BC}}$ \\
\hline 20 & $2.85^{\mathrm{Ab}}$ & $1.7^{\mathrm{Db}}$ & $1.73^{\mathrm{Db}}$ & $1.82^{\mathrm{Cb}}$ & $1.89^{\mathrm{cb}}$ & $1.96^{\mathrm{Bb}}$ \\
\hline 25 & $3.2^{\mathrm{Aa}}$ & $2.4^{\mathrm{Ca}}$ & $2.38^{\mathrm{Ca}}$ & $2.42^{\mathrm{Ca}}$ & $2.52^{\mathrm{Ba}}$ & $2.54^{\mathrm{Ba}}$ \\
\hline
\end{tabular}

TBHQ: tetra butyled hydroxyl quanine

Each value is an average of three determinations \pm standard devasion

in column; means with the same small supercript letters are not significantly different at $0.05 \%$.

in a raw means with the same capital superscript letters are not significantly different at $0.05 \%$

* Free from antioxidants

\section{CONCLUSION}

From the previous results, it could be concluded that, the antioxidative activity of Defatted black rice bran ethanolic extracts was greater than those of Defatted white rice bran, Black rice hull and White rice hull. The use of ethanolic extracted from defatted black rice bran, defatted white rice bran, black rice hull and white rice hull could be added at levels of $400 \mathrm{ppm}$ to increase the heat stability of oils

\section{REFERENCES}

Adom, K. K. and R. H. Liu (2002). Antioxidant activity of grains. J. Agric. Food Chem. 50:6182-6187.

Ali, R. M. (2010). Improvement the stability of fried sunflower oil by using different levels of Pomposia (Syzyyium cumini). Elec. J. Env., Agric. Food Chem., 9(2): 396-403.

Araba, F., I. Alemzadehb and V. Maghsoudib (2011). Determination of antioxidant component and activity of rice bran extract . Chemistry and Chemical Engineering , $4: 120-128$.
Basuny, A.M., M. A. Shaker and M. K. Sahar (2013). Polyphenolic compounds of eggplant peel juice as a natural antioxidant for the stability of sunflower oil during deep-fat frying. Curr. Res. Microbiol Biotechnol., 1(1): 1-8

Bonoli, M., V. Verardo, E. Marconi and M. F. Caboni (2004). Antioxidant phenols in barley (Hordeum vulgare L.) flour: comparative spectrophotometric study among extraction methods of free and bound phenolic compounds. Journal of Agricultural and Food Chemistry, 52: 5195-5200.

Butsat, S. and S. Siriamornpun (2010). Antioxidant capacities and phenolic compounds of the husk, bran and endosperm of Thai rice. Food Chem., 119, 606-613.

Delfanian, M., E.R. Kenari and A.M. Sahari (2016). Utilization of Jujube Fruit (Ziziphusmauritiana Lam.) Extracts as Natural Antioxidants in Stability of Frying Oil. International Journal of Food Properties, 19:789-801.

Devi, R. R., A. J. Jayalekshmy and C. Arumughan (2007). Antioxidant efficacy 
of phytochemical extracts from defatted rice bran in the bulk oil system. Food Chem., 104: 658-664.

Evangelisli, F., P. Zunin, E. Tisconia, R. Petacchi, G. Drava and S. Lanteri (1997). Stability to oxidation of virgin olive oils as related to olive conditions: Study of polar compounds by chemometric methods. J. of Am. Oil. Chem. Soc., 74(8): 10 171022.

Goufo, P., J. Pereira, N. Figueiredo, M. B. P. P. Oliveira, C. Carranca and E. A. S. Rosa (2014). Effect of elevated carbon dioxide (CO2) on phenolic acids, flavonoids, tocopherols, tocotrienols, coryzanol and antioxidant capacities of rice (Oryza sativa L.). J. Cereal Sci. 59:15-24.

Hosseini, H., M. Ghorbani, N. Meshginfar and A.S. Mahoonak (2016). A Review on frying: procedure, fat, deterioration progress and health hazards. J. of Am .Oil .Chem .Soc., 93, 445-466.

Innawonga, B., P. Mallikarjunana and J. E. Marcyb (2004). The determination of frying oil quality using achemosenory system. Lebensm-Wiss.u-Technol. 37:35-41

Iqbal, S., M. I. Bhanger and F. Anwar (2005). Antioxidant properties and components of somecommercially available varieties of rice bran in Pakistan. Food Chem., 93:265-272.

Jeon, K. I., E. J. Park, H. R. Park, Y. J. Jeon, S. H. Cha and S. C. Lee (2006). Antioxidant activity of far-infrared radiated rice hull extracts on reactive oxygen species scavenging and oxidative DNA damage in human lymphocytes. J. of Medicine and Food , 9: 42-48.

Lee, S.C., J.H. Kim, K.C. Nam and D.U. Ahn (2003). Antioxidant properties of far infrared-treated rice hull extract in irradiated raw and cooked turkey breast. J. Food Sci. 68: 1904-1909

Leonard, W.A., A.E. Woods and M.K. Wells (1987). Food Composition and Analysis.Publ. by Van Nastr and Rinhold Com. New York. pp. 255-258.
Liyana-Pathirana, C.M. and F. Shahidi (2007). Antioxidant and free radical scavenging activities of whole wheat and milling fractions. Food Chem. 101, 11511157.

McKeehen, J. D., R. H. Busch and R. G. Fulcher (1999). Evaluation of wheat (Triticum aestivum L.) phenolic acids during grain development and contribution of Fusarium resistance. J. of Agric. and Food Chem ., 47: 1476-1482.

Mohdaly, A., M. A. Sarhan, I. Smetanska and A. Mahmoud (2010). Antioxidant properties of various solvent extracts of potato peels, sugar beet pulp, and sesame cake. J. of the Sci. of Food and Agric., 90: 218-226.

Nam, S. H., S. P. Choi, M. Y. Kang, H. J. Koh, N. Kozukue and M. Griedman (2006). Antioxidative activities of bran extract from twenty one pigmented rice cultivars. Food Chem., 94 : 613-620.

Ordonez, J. D., M. A. Gomez and M. I. Vattuone (2006). Antioxidant activities of Sechiumedule (Jacq.) Swartz extracts. Food Chem., 97: 452-458.

Orthpoefer, F.T. (1996). Rice Bran Oil: Healthy lipid Source. Food Tech. December: 62-64.

Osawa, T. (1999). Protective role of rice polyphenols in oxidative stress. Anticancer Res., 19: 3645- 3650 (inJapanese).

Pitchaporn, W., K. Niwat and N. S. Sirithon (2016). Bioactive compounds and antioxidant properties of different solvent extracts derived from Thai rice byproducts.Appl Biol Chem ., 59(3): 373384

Pyo, Y., T. LE, L. Logendra and R.T. Rosen (2004). Antioxidant activity and phenolic compounds of Swiss chard (Beta vulgaris subspecies cycla) extracts. Food Chem., 85, 19-26.

Sahin, S., M. Bilgin, E. Sayım and B. Suvenilir (2017). Effects of natural antioxidants in the improvement of corn oil quality: olive leaf vs. lemon balm. 
International Journal of Food Science and Technology,52, 374-380.

Scalbert, A., I.T. Johnson and M. Saltmarsh (2005). Polyphenols: antioxidants and beyond. Am. J. of Clin.Nutr., 81: 215217.

Sidwell, C. G., H. Saiwin, M. Benca and J.H. Mitechell (1990). The use of thiobarbituric acid as a measure of fat oxidation. Am. of Oil Chem. Soci., 3(12): 603-606.

Steell, R.G. and J.H. Torrie (1980). Principles and procedures of statistics.2nd Ed. pp 120. McGraw-Hill, New York, USA.

Tsaknis, J., V. Spiliotis, S. Lalas, V. Gergis and V. Dourtoglou (1999). Quality Changes of Moring aoleifera, Variety Mbololo of Kenya Seed Oil During Frying. GrasasYAceites, 50: 37-48

Upadhyay, R., S. Sehwag and Niwas Mishra H. (2017). Chemometric approach to develop frying stable sunflower oil blends stabilized with oleoresin rosemary and ascorbyl palmitate. Food Chem, 218, 496-504.

Walter, M. and E. Marchesan (2011). Phenolic compounds and antioxidant activity of rice.Braz. arch. biol. technol.,.54 (.2) Curitiba Mar./Apr.
Wu, P.F. and W.W. Nawar (1986). A technique for monitoring the quality of used frying oils . J. of the Am. Oil Chem, Soci., 63: 1363-1367

Yao, Y., W. Sang, M. Zhou and R. Ren (2010). Antioxidant and $\alpha$-glucosidase inhibitory activity of colored grains in China. J. Agric Food Chem., 58(2):7704.

Yawadio, R., S. Tanimori and N. Morita (2007). Identification of phenolic compounds isolated from pigmented rices and their aldose reductase inhibitory activities. Food Chem, 101, 1616-1625.

Zaupa, M., L. Calani, D.D. Rio, F. Brighenti and N. Pellegrini (2015). Characterization of total antioxidant capacity and polyphenolic compounds of differently pigmented rice varieties and their changes during domestic cooking. Food Chem, 187, 338-347.

Zhang, M., B. Guo, R. Zhang, J. Chi, Z. We, Z. Xu, Y. Zhang and X. Tang (2006). Separation, purification and identification of antioxidant compositions in black rice. AgricSci China, 5, 431- 440. 


\section{النشاط المضاد للاكسده المحتمل لمخلفات ضرب وتبيض الارز}

\section{موسى عبده سالم(1) ، أحمد محمد عبدالرازق سرور(2) ، محمد أحمد البنا(2)}

(1) قسم علوم و تكنولوجيا الأغذية كليه الزراعه جامعه طنطا

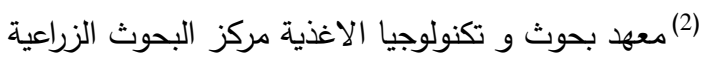

الملخص العربى

أجرى هذا البحث بهذف الحصول على بعض المركبات الفينولية المضادة للأكسدة الطبيعية المستخلصة من ضرب وتبيض الأرز مثل رجيع الكون الأسود منزوع الدهن ورجيع الكون الابيض منزوع الدهن وقثور الأرز الأبيض وقشور الأرز

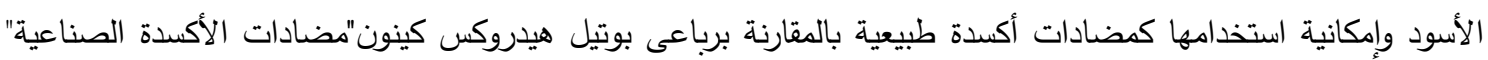
بإضافتها إلى زيت بذرة القطن أثناء تحمير البطاطس على فترات بمعدل 5 ساعات يوميا لمدة تصل إلى 25 ساعة. وقد أظهرت النتائج أن الايثانول كان أفضل مذيب لاستخلاص المواد المضادة للأكسدة حيث كانت الكمية المستخلصة من رجيع الكون الأسود منزوع الدهن ، رجيع الكون الابيض منزوع الدهن ، قشورالأرز الأسود ، قشورالارزالابيض هى:

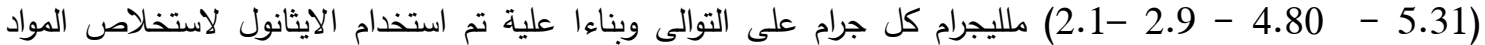
المضادة للاكسدة اللازمة لاستكمال باقى التجارب. واظهر النتائج ان المستخلص الايثانولى لرجيع الكون الأسود منزوع الدهن يملك اعلي نسبه نثاط من بين المستخلصات

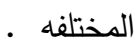
وبتفريد المركبات الفينولية لمستخلصات المخلفات السابقة الذكر أظهر أنها تحتوى على حامض (الفيريوليك والفاليك

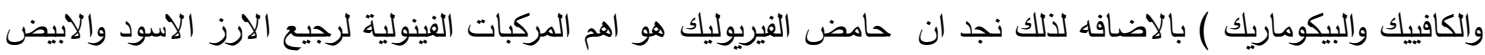
منزوع الدهن و قثور الارز الاسود بينما كان حامض الكافييك هو الهم المركبات الفينولية لقشور الارز الابيض.

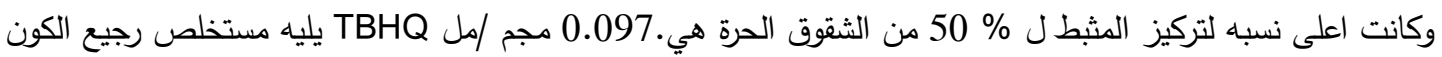

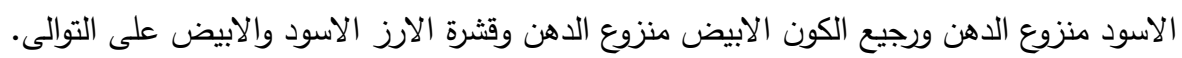

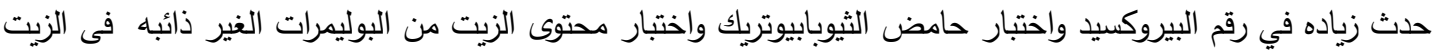

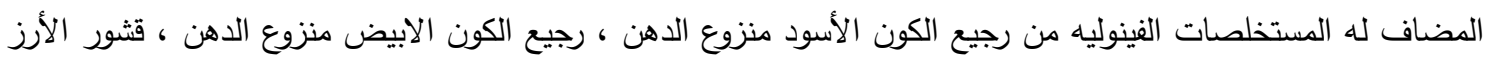
الأسود ، قشور الارز الابيض عند مستوي 400 جزء فى المليون و200 جزء فى المليون من رباعى بوتيل هيدروكس كينون"مضادات الأكسدة الصناعية" بزياده وقت التحمير بالاضافه لذلك نجد ان مستخلص الايثانولى لرجيع الارز الاسود اكثر المستخلصات الفينوليه فاعليه من المستخلصات الايثانوليه لمخلفات ضرب وتبيض الارز عند مستوي 400 جزء فى لهى المليون 200 جزء فى المليون من رباعى بوتيل هيدروكس كينون"مضادات الأكسدة الصناعية". 
M. A. Salem, et al., 